\title{
Sprovë për një periodizim të shkrimit të shqipes në Elbasan
}

\author{
Ruzhdi Stringa
}

Në themel të një periodizimi të mundshëm të shkrimit të shqipes në Elbasan kemi vënë ndryshimin e emrit të këtij qyteti në rrjedhë të shekujve. Tre janë emrat kryesorë që na japin kronikat historike:

1. Skampin (Koha e Skampinit)

2. Valm (Koha e Valmit)

3. Elbasan (Koha e Elbasanit)

Koha e Skampinit. Fillimet e këtij makrotoponimi shkojnë gjer në shek. II. Njohja jonë saktësohet në vitin $160^{1}$. Në këtë vit shënohet “...historia e dokumentuar e Skampës..., por kjo nuk do të thotë se Skampa e vjetër nuk ka ekzistuar edhe para kësaj date" ${ }^{2}$. Skampini, që rrethohej në ato kohë nga një varg venbanimesh të lashta, si Shkëmbi i Shlliut, Shkëmbi Mbret, Kalatë e Lleshanit, Gradishtës etj., kishte një fortesë të madhe fushore me një katedrale të Shën Pjetrit që përmendet më $519^{3}$. Kjo trashëgimi e shenjtë nis që së lashti me veprimtarinë e Shën Palit. F. Noli i përmend këto fakte në shkrimet e veta dhe i quan të rëndësishme edhe në fushën e gjuhës. Ai pyet retorikisht: "Shënt Pauli ç'gjuhë ungjillëzimi përdori në Ilirikum (Illyricum)? Përgjigja është e lehtë - ose shqip, ose latinisht”“. Dhe pikërisht

1 Viti 160 shënohet në një gur varri, gjetur në kalanë e Elbasanit. Aty, mes të tjerash, flitet për një Mark Sabitius "scampiensis"; është një dokument shkrimi që vërteton mirë se Skampini është po Elbasani i sotëm (Muzeu i Elbasanit).

2 S. Adhami, Monumentet e kulturës në Shqipëri, T.1958, f. 89.

3 L. Tacchella, Le antiche Sedi episcopali latine, grecche e bulgare dell' Albania Etnica e della Macedonia, Milano, 1990, f. 101. (shih: "Fjala e lirë" 18. IV. 1992).

4 F. Noli, Tradiciet fetare, Vepra 5, T. 1988, f. 236. 
në shek. VI duhet ngritur hipoteza e shkrimit të shqipes në Skampin, kur Episkopata e këtij qyteti varej nga Metropolitana e Durrësit, qytet i madh ky e i përmendur në kulturë e art. Në mos vepra të plota, shënime e fragmente shqip duhet të ketë pasur nëpër shkrime e raporte prelatësh e udhëtarësh, por kjo periudhë e hamendësuar e shkrimit të shqipes qe fatkeqe për faktorët e vet historikë. Kjo kohë përkon me ndryshime të rëndësishme cilësore të ilirishtes, e cila tashmë ishte larguar nga gjëllimi për t’ia lëshuar vendin bijës së vet, shqipes dhe "Ky evolucion i shkallëshkallshëm, pas gjithë gjasash, duhet të jetë kryer, jo më vonë se fundi i shek. IV të erës sonë dhe atëherë filloi dhe historia e mirëfilltë e gjuhës shqipe"s, megjithëse "Terminus ab quo i kësaj faze, me një farë përafërie, mund të merret fundi i shek. I ose fillimi i shek. II. ...Kjo fazë e parë mund të shpihet gjer në fund të shek. IV

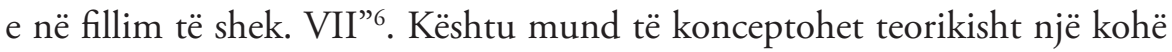
skampine e shkrimit të shqipes në Elbasan, që gjen shprehjen e vet praktike në ca antroponime e etnonime. Vështrohen si mbetëza tepër të lashta shkrimore iliro-shqipe, megjithëse ende të pasaktësuara mirë gjuhësisht, ca emra njerëzish ose fisesh që janë gjetur në kohën tonë në Elbasan e përreth tij, si Naevia, Itia, Plato, Dona, Parthinus, Apudia, Kailla, Tritos ${ }^{7} \mathrm{Lab}^{8}$ etj. Si më të lashtën fjalë shqipe të kësaj periudhe skampine të shkrimit të shqipes, mund të përmendim emrin familjar Sabitius. Po të veçojmë elementin fundor (i)us, që shfaqet me vlera latinizuese, dukuri kjo që ka vazhduar edhe më vonë, si te Barletius, që shqiptohet Barleci dhe Barleti, mbetet forma $\underline{\text { Sabit }}(\underline{\text { Sabic)}}$. Kjo formë (sipas rindërtimit tonë $\mathrm{Sa}(\mathrm{n})$-bit/bic) të sjell ndër mend sot shumë variante toponimesh që kanë rrënjë të përbashkët me emrin familjar të ushtarit skampinas, si Shënmitër, Shumitër, Shmitër, Shënbitër, Shbitër etj.

Koha e Valmit. Periudha e dytë që mundëson shkrimin e shqipes në Elbasan do lidhur me emrin e Valmit, fillimet e të cilit vështirë të datohen me saktësi, kur dihet se një bashkëpërdorim i tij me Skampinin tejzgjatet ende për hir të një tradite latine që ruan emërtimet e vjetra. Emri i qytetit, Skampini, zhvendoset për të emërtuar lumin aty pranë, Genusin, që harrohet. Një

5 Sh. Demiraj, Gjuha shqipe dhe historia e saj, T. 1988, f. 203.

6 M. Domi, Formimi i gjuhës shqipe, probleme dhe detyra, “Nëntori" 8, 1982, f. 42.

7 V. Toçi, Të dhëna mbi onomastikën ilire në Dyrrah dhë qendra të tjera të vendit tonë, "Konferenca e dytë e studimeve albanologjike", T. 1969, f. 375.

8 Etnonimi Lab dokumentohet në gjetjet e Kodrës së Kishës (Tepe), më 1968. 
gjë e tillë del në një përshkrim anonim të vitit $1303^{\circ}$, ku emri shfaqet me ndërrimin fonetik a(ë)-u (Skumpino), d.m.th. “...Shkumbin me errësim të ë-së paratheksore në u në dialektin përkatës të Shqipërisë së mesme"10, por edhe Scampinium, trajtë e vjetër që ishte largësuar me kohë nga ndërgjegja e folësve vendës $(1338)^{11}$. Emri Valm u përdor në vend të Skampinit, kur sërish, në atë truall, pas ndonjë shkatërrimi a djegieje (braktisjeje), filloi jetën një qendër e re urbane. Kohëzgjatja e këtij makrotoponimi të dytë s'është as fort e qartë, as fort e dokumentuar mirë. E përmend Marin Barleti “... qytetin e Valmëve të rrënuar nga themelet..."12. Këtë "Urbs Valmorum"13 Barleti e zë në gojë edhe si vendlindje të Moisi Golemit. Kjo kohë e Valmit lidhet me ngjarje thelbësore për etninë tonë. Tani ka argumente më bindëse për shkrimin e shqipes. Në qendër të truallit shqiptar del shteti i Arbërit me kredi edhe në fushën e marrëdhënieve ndërkombëtare (1208-1215) ${ }^{14}$ dhe përpjekje janë bërë për ta “...kërkuar epiqendrën e Arbërit përreth Elbasanit të sotëm. S'ka asnjë dyshim se, që nga mesi i shek. XIII, e pakta, gjer në fillim të shek. XIV, Arbëri shtrihet nga të dy anët e Shkumbinit" ${ }^{15}$. Komentues të huaj, kur shpjegojnë toponiminë në këngën e Rolandit, në një vend sqarojnë se "...Albanie - asht - Albanum i lashtë, sot Elbasan"16. Krijohen principatat e mëdha shqiptare, që bashkojnë trojet shqiptare (1379). Karl Topia më 1380 ndërton manastirin e famshëm të Shijonit, fillimet e të cilit errësohen shumë larg në kohë. Ai mbetet në historinë e vendit tonë qendër bashkimi, kulture e arti, tregtie etj. Shkrimi i shqipes kësaj kohe duhet të ketë nisur për së mbari. Dëshmia e Guliem Adaes ${ }^{17}$ mund të ketë lidhje me libra të kësaj kohe dhe shkrimi i shqipes të ketë gjetur truall zhvillimi në kohën kur “...fusha e Elbasanit, me gjithë qytetin e Valmëve u përkiste Arianitëve, Gjergjit vetë”18

9 Burime të zgjedhura për historinë e Shqiprisë, vëll. II, T. 1962, f. 110.

10 E. Cabej, Problemi i vendit të formimit të gjuhës shqipe, Studime gjuhësore V, P. 1977, f. 21.

11 Vepër e cituar, Nr. 9, f. 119.

12 M. Barleti, Histori e Skënderbeut, T. 1964, f. 481.

13 M. Barleti, Vepër e cituar, Nr. 12, f. 83.

14 Burime të zgjedhura për historinë e Shqipërisë, Vëll. II, T. 1962, f. 83.

15 Dh. Shuteriqi, Një mbishkrim i Arbërit (1190-1216) dhe mbishkrime të tjera, Studime historike, 3, 1967, f. 149.

16 K. Luka, Toponimia shqiptare në Kangën e Rolandit..., Studime historike, 2, 1967, f. 135-136.

17 Guliem Adae, i njohur me emrin Brokard, në një relacion të vitit 1332 shkruan: "Sadoqë shqiptarët kanë një gjuhë fare të ndryshme nga gjuha latine, prapë ata kanë në përdorim dhe në tërë librat e tyre shkronjën latine".

18 Dh. Shuteriqi, Arianitët - Zotërimet, Studime historike, 1, 1967, f. 11. 
dhe bënte pjesë në shtetin e Skënderbeut. Ka pastaj një dëshmi që duhet mbajtur mirë parasysh, se lidhet drejtpërsëdrejti me një trashëgimi të lashtë shkrimore në vendin tonë. Vihet re një qëndrueshmëri drejtshkrimore me vijim shekullor. Eshtë fjala për dyzimin e zanoreve të gjata, që praktikohet nga gjithë shkrimtarët e vjetër, por edhe më vonë. "...Prania e një norme të tillë drejtshkrimore në veprat e shkrimtarëve të vjetër shqiptarë, përkëtej dhe përtej Adriatikut, nuk mund të jetë një rastësi, as diçka e përftuar nën ndikimin e përbashkët të drejtshkrimit të ndonjë gjuhe tjetër" ${ }^{19}$. Kjo dukuri është e lashtë, por edhe vendëse, që u nxit së tepërmi, do të thonim, nga shteti i bashkuar i Skënderbeut. Një normë e tillë gjen zbatim praktik të vazhdueshëm edhe në shkrime të Elbasanit e të Shqipërisë së Mesme. I dyzon zanoret Budi (1620), Anonimi i Elbasanit (shek. XVII), mbishkrimi shqip i Ardenicës $(1731)^{20}$, Dhaskal Todri (shek. XVIII), dorëshkrimi i Simonit (shek.XIX) ${ }^{21}$ e të tjerë më të rinj si L. Nosi (1910), F. Papajani (1930). Pikërisht kësaj tradite në Elbasan i duhet kërkuar burimi në kohën e Valmit, që mundëson dukshëm shkrimin e shqipes, si qendër e re urbane në truallin e lashtë të Skampinit, duke ruajtur ende lidhjet e shumëllojshme me Durrësin e viset përreth. Fundi i kohës së Valmit përkon me mërgimin e arbëreshëve jashtë vendit, sidomos në Itali. Edhe sot ka atje mjaft mbiemra që të kujtojnë fise e fshatra të Shqipërisë së Mesme, si "Gramshi, Keta, Manes, Mates, Matranga, Mirakko, Muzaki, Polisi, Rada, Skura etj.”22. Kështu kultura shqiptare u gjend e ndarë nga zhvillimi i natyrshëm krahas vendeve të tjera të Evropës Perëndimore. Nga njëra anë, nga gjiri i mërgatës shqiptare të asaj kohe dalin humanistët shqiptarë dhe, nga ana tjetër, në trojet shqiptare kultura vazhdon në kushtet e sundimit osman.

Koha e Elbasanit. Si kufi nistor të kësaj periudhe marrim rindërtimin e kalasë së Valmit (1466) ${ }^{23}$. Megjithatë kjo datë mbetet formale, se gjatë shek. XV kështjella qe vetëm një qendër ushtarake osmane. Si ruajtës e vazhdues të kulturës arbëreshe, në këto kushte mbetën vendësit përreth, si edhe kishat, kuvendet e manastiret, që vijnë gjithnjë duke u rralluar. Ne nuk dimë gjë se ç’u bënë pasjet kulturore të Polisit, Mirakës, Shëngjergjit, Martaneshit,

19 Sh. Demiraj, Gjuha shqipedhe historia e saj, T. 1988, f. 252.

20 Th. Popa, Materialet epigrafike kishtare të vendit si burime për historinë e kulturës së popullit tonë, Konferenca e parë e studimeve albanologjike, T. 1965, f. 570.

21 K. Cipo, Një sy rreth dorëshkrimit të Simonit, Studime filologjike, 1, 1964, f. 185.

22 E. Cabej, Histori gjuhësore dhe strukturë dialektore e arbërishtes së Italisë, Stdime gjuhësore V, P. 1977, f. 71.

23 F. Noli, Vepra 4, T. 1989, f. 583. 


\section{Albanon}

Revistë kulturore

Kërrabës, Çermënikës, Shpatit etj., kujtimin e të cilave e ruan ndonjë shënim udhëtarësh ose gojëdhënat e folklori. Një pjesë e tyre u ruajt në ato pak qendra të vjetra kulture që i shpëtuan kohës, si Manastiri i Shijonit, ku $\mathrm{u}$ fsheh shekuj me rradhë dorëshkrimi anonim i Elbasanit ${ }^{24}$. Duhet thënë se “...Edhe pse nuk mund të mohohet roli i Mehmetit II në ngritjen e fortesës së Elbasanit, nuk duhet t'i njihet atij ... edhe merita e themeluesit të vetë qytetit të Elbasanit, në kuptimin që qyteti, mori fill vetëm me rindërtimin e fortesës" ${ }^{25}$. Në vend të emrit të mëparshëm (Valm), tradita kalimtare shënon emrin Qytet i Ri (Neokastër ose Terranova). Lidhur me këtë, M.Barleti jep këtë shënim për Valmin: “...të quajtur tani nga tanët qytet”26. Shumë vonë, emri i Elbasanit, përbërja fonetike e të cilit u ngjiz nga shqipfolësit përreth, u përgjithësua kudo, edhe në literaturë, brenda e jashtë Shqipërisë. Aftësitë punuese të vendësve dhe kushtet fiziko-gjeografike të këtij qyteti i dhanë shkas zhvillimit të mirë ekonomik e kulturor. Me zbehjen e Durrësit si qytet i madh e qendër kulturore, vlera urbane e Elabasanit rritet së tepërmi dhe jo vetëm për Shqipërinë e Mesme. Aty dhe në viset përreth jeton e punon një numër i madh njerëzish të kulturuar, veprimtaria e të cilëve ose humbi, ose njihet fare pak. Në krye të vendit rri Onufri, që pikturon me aftësi e talent në kishat e vogla të Shpatit e gjetkë (1554). Tek ai shfaqen shenja të qarta lidhjeje me pikturën e vendeve perëndimore. Ka edhe të tjerë që shquhen, si Nikolla, i biri i Onufrit (1578), inxhinierët e talentuar Sedefqar Mehmeti $^{27}$ (1565-1625), arkitekt Kasemi (1570-1656), arkitekt Sinani (vdekur 1620), Mustafa Meremetçiu etj. Si pasardhës i këtyre njerëzve të kulturuar, që dha ndimesë në shkrimin e shqipes në Elbasan, ose të paktën "si bashkëkohës i Onufrit"28, ka vendin e vet edhe autori anonim i Elbasanit, që sikur paralajmëron një plejadë të tërë gjuhëtarësh që nxori qyteti i Elbasanit, që nga Dhaskal Todri e Kristoforidhi e gjer te Xhuvani, Cipo, Domi, Dodbiba, Çeliku etj. Kohëshkrimi i Mesharit anonim të Elbasanit është i diskutueshëm, sepse ka mendime që e shohin të shek. XVII, ose edhe të shek. XVIII. Mund të përmendim githashtu si dokument shkrimor të shqipes në Elbasan edhe dy vargje të një kënge të shkruar me gërma arabe

24 M.Domi, Rreth autorit dhe kohës së dorëshkrimit elbasanas me shqipërim copash të ungjillit, Konferenca e parë e studimeve albanologjike, T. 1965, f. 270.

25 V.Buharaja, Rreth mbishkrimeve të fortesës së Elbasanit, Studime historike, 1, 1967, f. 101.

26 M. Barleti, Historia e Skënderbeut, T. 1964, f. 481.

27 E. Celebiu, Shqipnia para dy shekujsh (përkthim), T. 1930, f. 129.

28 I. Zamputi, Diskutim rreth kumtesës së Prof. M. Domit, Konferenca e parë e studimeve albanologjike, T. 1965, f. 400. 
në vitin $1650^{29}$. Kjo duhet kuptuar si një përpjekje e elbasanasve myslimanë për t'u lejuar nga osmanët të shkruanin shqip ${ }^{30}$. Kemi shfaqur mendimin se dorëshkrimi anonim i Elbasanit është shkruar para kësaj date $(1650)^{31}$.

Duke përfunduar theksojmë se, tri kohët, që lidhen me fillimin dhe rifillimin e jetës urbane gjatë shekujve në këtë qendër të rëndësishme tregtare e kulturore në luginën e Shkumbinit, shënohen nga tri makrotoponimet e njëpasnjëshme, te të cilat $\mathrm{u}$ mbështetëm për të hamendësuar periudhat e shkrimit të shqipes në Elbasan.

29 Dh. Shuteriqi, Shkrimet e vjetra shqipe 1330-1880, T. 1976, f. 78.

30 Përpjekje të tilla janë bërë edhe në shekujt e mëvonshëm nga shqiptarët. Le të kujtojmë abetaren shqip, me gërma arabe të Daut Boriçit (shek. XIX).

31 R. Stringa, Kohëshkrimi i Mesharit anonim të Elbasanit, Fjala e lirë, 7 dhjetor 1991. 